\title{
"Places you shouldn't go to": (Im)mobility, violence and democracy in Brazil and South Africa
}

Oñati SOCiO-Legal Series Volume 11, Issue 6 (2021), 1365-1391: SOCIAL CONTROL, JUDICIALIZATION OF SOCIAL PROBLEMS AND GOVERNANCE OF SECURITY IN COMPARATIVE PERSPECTIVES DOI LINK: HTTPS://DOI.ORG/10.35295/OSLS.IISL/0000-0000-0000-1221

ReCEIVEd 14 January 2021, ACCEPTED 27 August 2021, Version of ReCord Published 01 DECEMBER 2022

\section{ELIZABETE RibEIRO ALBERNAZ* (D)}

\author{
LENIN PIRES* (D)
}

\section{Abstract}

Pursuing the broader political effects of the relationship between violence, mobility, and inequality, the article describes some of the grounded political-economies (re)producing social inequalities in Brazil and South Africa, and a discontinuous experience of the urban space. This fragmented spatial experience is produced by the simultaneous operation of a discursive apparatus projecting a split ideal of "city", and grounded social mechanics, in the intersection of values and power relations. In Johannesburg, South Africa, we've described the creation of Maboneng, a "urban development project", to highlight the role of social mobility and growing class aspirations as powerful political vehicles for neoliberal markets reissuing old apartheid socio-spatial divisions. In Rio de Janeiro, Brazil, we've explored the relationship between the State and its margins to understand the production of the milícia as a violent antimodern capitalist venture, aiming to control the circulation of people, capital and political support in the city.

\section{Key words}

Violence; mobility; social inequalities

\footnotetext{
* Elizabete Albernaz is a Ph.D. in Anthropology, Visiting Researcher at Wits University (South Africa), and vice-coordinator of the Laboratory of Studies on Conflict, Citizenship and Public Security (LAESP / UFF) at Universidade Federal Fluminense (UFF), Niterói, Brazil. Contact address: 501, Dumbarton Oaks, 2nd Avenue, Killarney, 2193, Johannesburg, South Africa. Email: elizabetealbernaz@id.uff.br

* Lenin Pires is a PhD in Anthropology, Professor of the Public Security Department and Director of the National Institute of Comparative Studies in Conflict Management (InCT-INEAC), both at Universidade Federal Fluminense (UFF), Niterói, Brazil. Contact address: Prof. Hernani Pires de Mello, 84 - Ingá, Niterói - RJ, 24210-130, Brazil. Email: leninpires@id.uff.br
} 


\section{Resumen}

Siguiendo los efectos políticos más amplios de la relación entre violencia, movilidad y desigualdad, el artículo describe la forma en que algunas políticas económicas arraigadas (re)producen desigualdades sociales en Brasil y Sudáfrica, una experiencia discontinua del espacio urbano. Esta experiencia espacial fragmentada es producto de la operación simultánea de un aparato discursivo que proyecta un ideal escindido de "ciudad" y mecanismos sociales arraigados, en una intersección de valores y relaciones de poder. En Johannesburgo, Sudáfrica, describimos la creación de Maboneng, un "proyecto de desarrollo urbano", para destacar el rol de la movilidad social y de las crecientes aspiraciones de clase como potentes vehículos políticos para que los mercados neoliberales reediten viejas divisiones socio-espaciales del apartheid. En Río de Janeiro, Brasil, analizamos la relación entre el Estado y sus márgenes a fin de entender la producción de la milícia como riesgo capitalista antimoderno violento que tiene el propósito de controlar la circulación de personas, capital y apoyo político.

\section{Palabras clave}

Violencia; movilidad; desigualdades sociales 


\section{Table of contents}

1. Introduction

1368

2. (Im)mobility and (in)security in Rio de Janeiro and Johannesburg.....

2.1. The case of Muzema: The milícia and the "war on crime" in Rio de Janeiro 1373

2.2. The case of Maboneng: Illegal migration and the "New Urban Wave"

1376

3. "Persistent precariousness" and the possibility of real democracy .......................... 1379

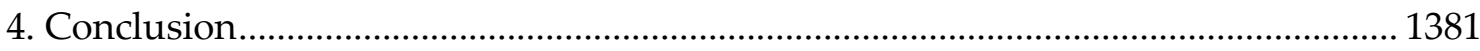

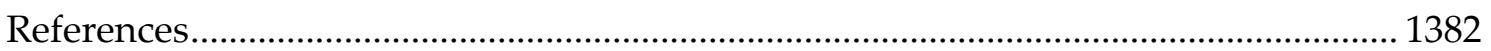




\section{Introduction}

According to the United Nations (UN), since 2005, half of the world's population has lived in cities (World Urbanization Prospects, 2014). Although many argue that modernity has greatly improved overall levels of human development (Shermer 2015, Pinker 2018, Rosling 2019) the marvels of modern urban societies do not benefit their participants equally. Since the 1980's, the aggravation of social inequalities caused by the persistent concentration of capital and income has gained dramatic contours. This growing distance between the wealthy and the poor challenges romantic images of the "urban", questions the possibility of a real democracy and re-addresses the radical question of the "right to the city" (Lefebvre 1968/1991, 1970/1999).

Based on extensive ethnographic field-work and bibliographic review, in the present article we expect to explore the complex relations between violence, mobility, and inequality in Brazil and South Africa, promoting the experience of a discontinuous militarized urban space, characterized by the coexistence of projected "havens" of safety and order, and pockets of crime, poverty and insecurity in both countries today. By contrastively comparing the two cases, we also expect to contribute to consolidating a "southern" perspective to the discussions addressing the production of restricted circulations worldwide, translated in the common experience of the growing distance between the wealthy and the poor in two major cities of the so-called "global-south", Rio de Janeiro and Johannesburg.

Broadly acknowledged as a shared reality to the neoliberal democracies of our times (Caldeira 1997, 2000, Graham 2011, Amar 2013, Omena de Melo 2017, Pires 2019, Pires et al. 2020, among others), this fragmented spatial experience is produced by the operation of a discursive apparatus projecting a split ideal of "city", commonly defined by the oppositions safe/unsafe and legal/illegal. This fragmented experience, produced by the operation of powerful (and sometimes ruthlessly violent) market forces, constitutes much of the contemporary experience of social inequalities felt by the inhabitants of cities and metro areas worldwide. As anthropologists, the relevant question, however, is how to build intelligible connections between the workings of those powerful forces, presently identified with the production of the neoliberal city, and the everyday life of real people in real-life settings. How those forces are felt by the common people and what vernacular is used to symbolise these relations. To respond to these concerns, in the present article, we've chosen to observe those forces "in movement". Moving through time, and space, through generations and social hierarchies, imprinting the

\footnotetext{
1 "Global South" is a politico-theoretical category that seeks to distance itself from old teleological and stigmatizing terminologies such as "third world" or "developing countries". The Global South adds another geopolitical division between countries that were victimized and the ones that have benefited from the colonial expansion of the capitalist system and its planet-wide social division of labor. This condition also implies a common political, theoretical and academic framework of concerns regarding the sharing of a "peripheral" position in the circulation of values, people and knowledge in the "global economy" (Silva 2008, Dias et al. 2008, Filho and Dias 2015, Hollington et al. 2015, Ribeiro et al. 2015). An important criticism of the concept, however, is that by thinking on a Global South in contrast to the "North" one does not consider the continuous influence of Northern ideological and material lineages in the so-called "postcolonial" world, embodied in the actions of their "economic elites" (Eriksen 2014). This post-colonial situation was also characterized as "subaltern" by some authors (Guha and Spivak 1988, Appadurai 2001, Santos 2002, Spivak 2010, among others).
} 
"spirit" of the city (Bell and De-Shalit 2013), the prevailing ethos that distinguishes them from any other human aglomerate like them, in the hearts and minds of their inhabitants.

We argue that, for the common person, mobility (or the lack of it) is the most frugal way to get in touch with the economic and political forces producing that fragmented social experience of the urban space. As movements through space are also indexes of social status, they can be good analytical keys to try to grasp the everyday, mundane expressions of long-term structures of social inequalities and their effects on people's lives. Therefore, moving away from the prevailing macro-economic framework of international studies addressing social inequality - centered on income, wealth, and consumption standards (Piketty 2014) ${ }^{2}$ - we're interested in the workings of localized grounded social mechanics, operating in the intersection of values (symbolic and economic) and power relations in Rio de Janeiro, the second most populous city in the southeast of Brazil, and Johannesburg, one of the capital-cities of South Africa, also the largest and wealthiest metro area in the country.

In the post-apartheid South Africa, we argue that those social forces are epitomized by "urban development" projects and the violence of what Martin J. Murray called "indifferent urbanism" (Murray 2008). With the Joburg case, we expect to underline the role of social mobility and class aspirations among the urban black (Melber 2016, Southall 2016) as powerful political vehicles for neoliberal markets reissuing old spatial divisions in significantly new ways. If the lights of Joburg, back in apartheid days, used to be the unequivocal sign of a "whites-only" society, the struggles for housing in the inner city area today will see black africans on both sides of the electrified fences. In Rio de Janeiro, the second major metropolitan area in Brazil, a highly militarized and fragmented urban landscape is being produced by the expansion of the "militia" - in Portuguese, milícia. The case of the Muzema, a favela controlled by the milícia in Rio de Janeiro, illustrates the nature of the capitalist venture implemented by those paramilitary groups using extortion and violence to establish their dominance over entire areas, controlling the mobility of people, capital and political support. The recent expansion of those groups shows that under very specific circumstances State powers can be monetized in ways that challenge not only more orthodox divisions between State, market and society, but between legal and illegal.

We expect to pursue the broader political effects of the phenomena under scrutiny based in the ethnographic observation of three interconnected dimensions: the discursive economies justifying the actions of official agencies against specific segments of the urban population; the nature of the conflicts related to social and spatial mobility in both contexts; and, finally, the grounded processes of "State formation" 3 emerging from the

\footnotetext{
${ }^{2}$ But also examples of work developed by the World Inequality Database (https://wid.world/), the World Income Inequality Database (https://www.wider.unu.edu/project/wiid-\%E2\%80\%93-world-incomeinequality-database), and the Inequality and Shared Prosperity reports and data (https://www.worldbank.org/en/topic/isp) (access 11 August 2021).

${ }^{3}$ The spatialized analysis of the everyday process of State formation reveals that, despite the pessimistic prognosis, the State is alive and well (Sharma 2006). Corruption scandals, inability to provide protection, failures in its distributive and welfare policies might project the impression of a dissolving State. The alleged symptoms of its Dissolution, we argue, are in fact reflections of changes in the cultural grounds of "State formation" (Krader 1970, Trouillot 2001, Ferguson and Gupta 2002, Krohn-Hansen and Nustad 2005, Ferguson 2006, 2014, Lima 2010, 2012).
} 
everyday administration of those conflicts in the present. By addressing the structural relationship between the State and its "margins" (Das and Poole 2004), the two cases brought to the present article greatly illustrate the part played by representations of "urban violence" in the spurious appropriation of an idea of State (Abrams 1988) by a myriad of positioned economic interests in both countries, as well as the systematic and widespread relations between crime and statal forms of social control (Comaroff and Comaroff 2016).

To conclude, after the presentation of the two cases, we present the idea of "persistent precariousness" as an apparatus of government articulating exclusion, subaltern integration and physical annihilation in the shaping of the urban landscape of Johannesburg and Rio de Janeiro (Pires 2017a, 2017b, Albernaz 2018). The idea is to underline the distinctive characteristics of the neoliberal era in the two capitalist democracies by depicting the State as a porous entity, the product of everyday, very mundane relations with society. Recognized by its effects more than by any other discernible a priori feature, ${ }^{4}$ we argue that in both cases those statal forms are operating to prevent (instead of promote) the establishment of a universal, egalitarian ideal of citizenship.

Ultimately, this perspective challenges the possibility of real democracy in countries overwhelmed by high levels of social and legal inequalities, like Brazil and South Africa.

\section{2. (Im)mobility and (in)security in Rio de Janeiro and Johannesburg}

Notably inspired by the "biopolitical approach" of Michel Foucault (1979, 1984, 2001, 2007) and the spatialized reading of Marxian theory of value by Henry Lefebvre and his urban manifesto on the "right to the city" (Lefebvre 1968/1991, 1970/1999), recent works addressing issues of "mobility" (or, again, the lack of it) widely acknowledge that the contemporary experiences of social inequalities involve the spatialization of historical power relations and the development of "bureaucracies of control", apparatuses of government, anointed by ideals of "public interest", restricting people's access to places (of living, working and amusement) but, most importantly, to wealth and social resources available in urban settings (Ribeiro and Santos 2017, Aguero and Perelman 2019).

In Brazil and South Africa, those long-term structures of inequalities were ultimately produced by the social organization of land ownership and labor, put in place by hundreds of years of colonialism, the atrocities of black slavery and the ulterior subaltern and many times violent integration of their non-white populations to the city as working class (Faoro 1958/2008, Pauw 1962, Holanda 1976, Van Onselen 2001, 2019, 2021). The gradual inscription of those historical developments in the urban space happened pari

\footnotetext{
${ }^{4}$ In that matter, we couldn't agree more with the diagnosis of Michel-Rolph Trouillot. “Thus this century opens on two sets of contradictory images: The power of the national state sometimes seems more visible and encroaching and sometimes less effective and less relevant. This paper explores how, as anthropologists, we can make sense of this tension and fully incorporate it into our analysis of the state. To do so, we need to recognize three related propositions: (1) state power has no institutional fixity on either theoretical or historical grounds. (2) Thus, state effects are never obtained solely through national institutions or in governmental sites. And (3) these two features, inherent in the capitalist State, have been exacerbated by globalization. Globalization thus authenticates a particular approach to the anthropology of the State, one that allows for a dual emphasis on theory and ethnography" (Trouillot 2001, 126).
} 
passu with the efforts of urban planners and engineers to create the transport infrastructure to move those working hands from their places of living to the centers of the emerging urban economies, with state bureaucracies growing against the spontaneous organization of the city based on uses, temperaments and tastes (Park 1979, Hannerz 1980, Geertz 2003). Although in South Africa this process had a more thorough state-led orientation, guided by apartheid and British colonial policies, developments of the post-apartheid era have brought the comparison with countries such as Brazil and more "soft" forms of segregation, incorporating ideals of social class to its racial component, to the forefront of the research agenda in the country (Terreblanche 2002, Melber 2016, Southall 2016, among many others).

The role of "urban violence", and the widespread fear of crime and victimization, have been considered key issues by scholars reflecting on the new forms of segregation and the long-term effects of transgenerational exposure to violence and crime over individuals and communities in South Africa (Spinks 2001, Lemanski 2004, Pillay 2008, Pinnock 2016, among others). Despite the polysemic nature of the expression (Silva 2004, 2008), urban violence is also known to exert a great impact on people's mobility in Brazil, not just in terms of their actual capacity to move through space but to navigate (especially upward) through social hierarchies (Virilio 1977/1986, Pires 2011). One important dimension bridging the realities of Brazil and South Africa, however, is the use of urban violence as a key vernacular to express collective anxieties related to the state of the economy and in politics, to "explain" the maladies inflicting the two countries (Caldeira 1997, 2000). That changed very little, which can be easily exemplified by a simple mental exercise; one that invites the reader to step in the imaginary shoes of an "unwary visitor" trying to navigate the dangers and delights of Rio de Janeiro and Johannesburg.

Whoever has the opportunity to visit those two major cities of the so-called "developing world" will probably be welcomed by friendly advice regarding the "places that you shouldn't go to". The distinctions can be both radical and oddly subtle. "You can walk safely here, but there [one street down] you shouldn't walk alone". And you better not dismiss the warnings! You can enter a favela in Rio de Janeiro and enjoy your best time at a local funk-music party; you can walk around Johannesburg inner city and visit the heritage sites. You can, and you should; but not freely. To see the sites in Johannesburg inner city you will be advised to walk only through its safety islands. "This part of the street is safe [referring to the segment of Commissioner Street monitored by one of the major private security companies operating in Joburg], but the other side [points to the opposite segment of the sidewalk] is dodgy; it might take longer, but if you want to walk around you should always use the safe routes". In Rio de Janeiro, the warnings would be slightly different. You would be advised to avoid the city "after the tunnel [the Rebouças Tunnel, connecting the wealthiest part of the city and its working-class suburbs]", for example, and not to make the mistake of accidentally entering a favela. "A tourist couple was shot the other day; they drove into the favela by mistake using WAZE 
[a community-driven map app] and the drug dealers opened fire on them", ${ }^{5}$ people might tell you, mentioning some recent cases (Martín 2015).

But if the problem of our hypothetical visitor is not knowing where to walk around safely, the issue for the inhabitants of those interdicted places, we could say, is "safety" itself. In Rio de Janeiro, the police are either killing or actively cooperating with illegal drug dealing factions, when not directly managing the illegality in those areas of the city (Menezes 2018, Farias et al. 2020, Pires et al. 2020). The military occupation of the favelas with the UPP project (in English, Pacification Police Units), followed by two years of federal intervention in Rio de Janeiro's public safety (2017-2018), and the remarkably homicidal government of Wilson Witzel (2019-2020), left behind a sad trail of death and police brutality. ${ }^{6}$ In Johannesburg inner city, the so-called "dark buildings", occupied by a mostly black migrant population, are also being systematically targeted by an articulated policy of police raids and mass evictions (Landau 2007, Wilhelm-Solomon 2020). ${ }^{7}$ The violence and, oftentimes, illegality of those massive operations led Murray to talk about a "Brazilianization" of Joburg urban landscape (Murray 2008, 228). As it should be clear by now, the right to move freely through the social hierarchies of the urban space is not just unevenly distributed, but is key to devising the limits of practical citizenship in Brazil and South Africa. ${ }^{8}$

Connecting both experiences, we devise the operation of a discursive apparatus articulating oppositions between safe/unsafe - legal/illegal, justifying the subaltern integration of segments of the "urban poor" (Bayat 2000, Mitlin and Satterthwaite 2013, Das and Randeria 2015, Nelson 2017). Loosely incorporated into the judicial-legal order of the city and stopped from benefiting fully from its economy, those segments are kept

\footnotetext{
${ }^{5}$ After many cases of people entering favelas inadvertently in Rio de Janeiro using WAZE, the app developers implemented new features to identify the so-called "risk areas" (in short, the favelas), alerting the users about the "non-go" zones in the city. Called WADA (Waze Avoid Areas), they materialize the idea that there are places that you shouldn't go (at least not by mistake) in cities such as Rio de Janeiro and Israel. Platform drivers can rely on a very similar service. For a comparative approach about the WADA, see Carraro 2019. The implementation of the system was associated with the "major events" era in Rio de Janeiro. For more about that, see Marshall 2016.

${ }^{6}$ In the years 2018 and 2019, the number of deaths resulting from police raids was 1740 and 1810, respectively. In 2020, only in the first four months, before the impeachment of the Governor Wilson Witzel, accused of fraud in the distribution of emergency health resources amid the COVID-19 pandemic, the police killed 741 people during raids and other interventions. For the numbers of police killings and more public safety statistics in Brazil, see Fórum Brasileiro de Segurança Pública (https://forumseguranca.org.br/anuario-brasileiro-seguranca-publica/).

7 See also the excellent article Johannesburg cannot police its future, written by Matthew Wilhelm-Solomon (2020a).

${ }^{8}$ Coincidentally or not (probably not), in the last 25 years, very similar social processes seem to be operating in highly urbanized areas on both sides of the Atlantic. Those processes were catalyzed by massive capital inflows from the so-called "major-events" economy, a strong vehicle of the neoliberal global capital exerting a strong influence over the formation of the democratic State in Brazil and South Africa during the 90s. In Rio, the 1992 UN Conference on Environment and Development (Rio-92) constitute the initial landmark of the "major-events era" in Brazil, followed by the 2007 Pan-American games, the 2014 FIFA World Cup and the 2016 Olympics, among many others. In South Africa, the 1995 Rugby World Cup included the country among the new favorite "southern" destinations for the major-events investment capital, followed by the 2010 FIFA World Cup and the 2015 Cricket World Cup, among others. Those forces, participating in the agreements around the redistribution of power in the post-authoritarian society, helped to shape the contemporary mechanics reproducing long-term structures of social inequalities in both countries (Benjamin et al. 1998, Gennari 2002).
} 
within a "safe" distance to serve the city as a working force. As epitomized by the South African case, controlling the circulation of people is strategic for the achievement of that authoritarian combination of civic inclusion through labor. Wherever that subaltern integration cannot be achieved, we observe the systematic elimination of those populations already subjected to the consequences of a precarious citizenship status, their legal, symbolic and many times material annihilation (Medeiros 2017, 2018, Da Silva 2019, Mbembe 2019).

In the following section, we will explore the discursive politics of fear framing the social experience of inequality in Johannesburg and Rio de Janeiro underlying the importance of a multi-sited observation (Marcus 1995) of the social processes building a situation, a place and its population as a "problem" (of safety, health...) and as a potential subject of public interventions. For us, the question is how those problematic situations gain repercussion (Thévenot 2006). ${ }^{9}$ Above all, we are interested in identifying who is the "public" and who is the "problem" for those interventions and how those positions are established. By doing so, we expect to illuminate the discursive practices drawing those lines, underlining its effects on segments of the urban poor, and on the conservative transformation of long-term structures of social inequality in Brazil and South Africa.

\subsection{The case of Muzema: The milícia and the "war on crime" in Rio de Janeiro}

In Rio de Janeiro, the second largest city in Brazil, the violent disputes over the control of illicit drug markets produced the traficante (drug dealer), the devil you know ${ }^{10}$ of the war on crime since the 1990s. Through its metonymic image, the poor, non-white, migrant population of the favelas was continuously submitted to the violence of their peripheral integration to the city (Preteceille and Valladares 2000, Mello and Silva 2012). Strongly conveyed by agents in the "State system" (Abrams 1998), that order of things found public support through the operation of a series of discursive strategies generating the political myth of an "urban war" (Leite 2012, 2014). But the "war on crime", as we well know, is a war on poverty; a war fought against the poor, and this warfare mythology displayed very serious socio-political consequences, ranging from everyday deadly violence to the furthering of a right-wing electoral scenario nationwide in Brazil. The production of favelas (slums) as places of exception, stripped of all legal and political protection, is a process that goes far beyond. Holders of precarious rights over the land on which they built their homes, those discredited segments are constantly victimized by arbitrary governmental actions, violence and corruption, being kept systematically apart from the usufruct of de facto universal rights.

The "social accumulation of violence" in Rio de Janeiro (Misse 2008, 2010) ${ }^{11}$ soon brought about another actor, a new form of violent regulation, to the forces organizing the circulation of people, capital and value in the city, blooming in the places of living of its working classes: the milícias ("militias"). Since 2006, when the former mayor of Rio de

\footnotetext{
${ }^{9}$ For a more clarifying discussion about the cultural process and everyday forms of this process in the Brazilian case, see Lima et al. 2017.

${ }^{10}$ Refers to the English expression "Better the devil you know than the devil you don't."

${ }^{11}$ The concept of "social accumulation of violence" was coined by the Brazilian sociologist Michel Misse to delimitate a historical process happening in the Rio de Janeiro Metropolitan Area since the 50's which involves the continuous production of "criminally subjected" social types by the reiterated contact of certain segments of the population with the criminal justice system (Misse 2008).
} 
Janeiro, César Maia, called them an initiative of "community self-defense", those groups have gone a long way towards expanding their control over entire areas of the city. ${ }^{12}$ In the early days of its regulatory project, the milícia found support among politicians and the general population in the promise to eliminate the selling and use of drugs, purging the vicious traficantes from the places of living belonging to the popular classes. Mostly composed of police officers and other actors connected to the State at first, inhabitants of those same working class areas, the milícia used to be seen as a "legitimate reaction" of those segments to protect their families and pacify their communities (Alves 2003, 2008, Cano and Duarte 2012, Rodrigues et al. 2018, among others). ${ }^{13}$

Years after that, not just their cadres, but their "business" broadened considerably. ${ }^{14}$ From charging for protection, to the regulation of legal and illegal markets (from cooking gas, housing, cable TV, and internet, to the selling of drugs and weaponry), the milícias recently reached unprecedented political horizons, expanding their electoral influence under the auspices of governmental authorities. ${ }^{15}$ An unaware audience might find the idea of the booming of those forms adjacent to the State a phenomenon highly dependent (not to say cooperative) on official agencies, sounding surprisingly contradictory. Maybe their marvel is caused by their tribute to old established liberal terminologies treating the "State" as a reified discrete entity, ruling society from above. In the present paper, we adopt a rather different take on that matter. The expansion of those marginal, semiofficial forms of governing like the milícia is approached as a political phenomenon expanding State powers using its "margins" as a powerful source of materiality (Das and Poole 2004). In that regard, the case narrated next can be illuminating.

On the morning of the $12^{\text {th }}$ of April 2019, the city of Rio de Janeiro woke up to the shocking headlines, Buildings collapse in the community of the West zone of Rio de Janeiro. ${ }^{16}$ Twenty-four people died. Many others saw their dreams of financial stability washed away together with their homes. The two buildings, both erected illegally by the milícia in an environmentally protected area, were located in a favela known as Muzema, a popular class area in the district of Jacarepaguá with 1,528 households and 5,500 inhabitants (Instituto Brasileiro de Geografia e Estatística - IBGE - 2010). ${ }^{17}$ Jacarepaguá

\footnotetext{
${ }^{12}$ Today, many similar groups with similar interests and activities are spread out, in more than 180 locations. They are investigated by Special Action Groups to Combat Organized Crime (Gaeco) of the Public Ministry and the General Department of Homicide and Protection of the Person (DGHPP) of the Civil Police. See Werneck and De Souza 2019.

13 "Milícias expulsam os traficantes de drogas e já controlam 92 favelas da cidade" (O Globo and Extra 2006).

${ }^{14}$ The more critical expansion of the milícia in Rio happened after the exhaustion of a period of almost 10 years of massive capital injection in the city propelled by the so called "mega-events", like the World Cup (2014), the Olympics (2016), and many others. The gentrifying effects of these mega-events, with the stigmatization and removal of entire communities that were unlucky enough to be in the way of progress, aimed to transform the city of Rio de Janeiro into a consumer good. See Sánchez and Broudehoux 2013.

${ }_{15}$ The politician's involvement with militia groups was the main point discussed by the Parliamentary Commission of Inquiry (CPI), from the Legislative Assembly of the State of Rio de Janeiro (Alerj), on the investigation regarding this issue that occurred in the last decade. The final report, published in 2008, suggested the indictment of 266 people, including seven politicians, suspected of connection with paramilitary groups in the Rio de Janeiro Metropolitan Area. In 2009, after the CPI of the Militias, 246 militiamen were arrested in the state, three times more than the previous year. See Marés et al. 2018.

${ }^{16}$ Prédios desabam em comunidade na zona oeste do Rio de Janeiro (Alfaya 2019).

${ }^{17}$ Muzema is a shanty town located in Itanhangá, a high-class neighborhood in the administrative region of Barra da Tijuca. The latter, in turn, corresponds to the $24^{\text {th }}$ Administrative Region of the city and, according
} 
is a historic stronghold of the milícia in the city of Rio de Janeiro and the consolidation of those groups benefited not only from the anxieties of a frightened working middle class living in the more affluent areas of the district. The milícias also grew in the regulatory gaps left by official agencies in areas like Muzema by granting this impoverished population access to goods and services that otherwise would be inaccessible to them such as the possibility of home ownership in an economically dynamic area of the city.

Although the "absence" of official regulation in strategic fields like housing and public security is the alleged cause of the booming of the milicias, their violent regulation of territories is surprisingly supported by a strong relationship with the State. To enjoy a certain lifestyle and the consumption standards associated with the middle classes (access to the internet, ownership of property) poor working classes living in the interstices of the formal city are forced to cope with some strict market rules. The main asset in this parallel market is "protection", a particularized version of safety. Protection not only from street crime and from the deleterious influence of the traficante, but also from the potential violence perpetrated by the milícia itself. To avoid that violence, the inhabitants of those areas have to channel their purchasing power to businesses and services directly controlled or associated with the milícia. More importantly, however, to benefit from the economic advantages of this violently regulated market, the popular classes have to vote for candidates sponsored by the milícia. The violation of those basic rules can have deadly consequences. ${ }^{18}$

Five months after the collapse of the buildings in Muzema, 17 arrest warrants had been issued against the milícia men and two suspension orders had closed two construction companies involved in this tragic real estate enterprise. Some of the accused were openly violent men, directly involved in the extortion of the local population, in homicides and in many other crimes. Others, however, were businessmen, people living in affluent suburbs, neighboring the poor Muzema and absorbing its low skilled workforce. ${ }^{19}$ The chief of the local milícia was also arrested later that same year; he was a higher officer of the Military Police of Rio de Janeiro (PMERJ). His former position within the State allowed him prestige and a certain status in the group, once he was able to use his direct influence inside the organization to assure direct collaboration and access to public resources allocated to the local military police units (guns, vehicles, staff). ${ }^{20}$

to City Hall data, concentrates a population of approximately 336 thousand inhabitants. Muzema has approximately 6,000 inhabitants, most of whom are poor, many from the states of Northeastern Brazil.

${ }_{18}$ These groups were responsible for the murder of city councilwoman Marielle Franco on 3/14/2018, whose motivation has not yet been established. At least according to the Rio de Janeiro Police investigation and prosecution by the Judicial System. The author of the shots that killed her, former police officer Ronnie Lessa, was part of one of these groups, known as the "Crime Office". He lived in the same condominium as the current President of the Republic, Jair Messias Bolsonaro, in the area known as Barra da Tijuca.

${ }^{19}$ One of those businessmen arrested in Freguesia, an upper-to-middle class area in Jacarepaguá, had moved more than 25 million reals for the branch of the Rio das Pedras milícia operating in the Muzema. His wife, a public servant working for the city, was accused of facilitating the registration of the irregular buildings by the Rio de Janeiro Municipality. For more about the businesses involved in the milícia operation, see article in Portuguese in Guimarães et al. 2019.

${ }^{20}$ Less than a month after his prison, he was invited to attend an event sponsored by the Military Police of Rio de Janeiro and was photographed walking freely among his fellow officers at the Police Academy, the institution responsible for forming the organization's higher ranks (he was himself a Major). See article in Portuguese, Resende 2019. 
The losses in the Muzema case were invaluable. The arrests might force those men to answer for their crimes, but it represents a legal imbroglio to the ones seeking compensation for their financial and existential losses. In August 2019, Muzema dwellers protested against their imminent eviction during a public audience to discuss the situation of the other six buildings comprising the real estate development owned by the milícia. Intermediated by a local politician, they occupied the tribunes of the City Council to try and pressure judicial authorities to suspend the demolition announcements. Years after the tragedy, the survivors and families of the deceased are still struggling, caught between financial debts, the bureaucracy of the State and the violence of their illegal landlords.

\subsection{The case of Maboneng: Illegal migration and the "New Urban Wave"}

In the middle of the Library Gardens Square at Johannesburg CBD (Central Business District), there is a statue of a black ${ }^{21}$ woman. Standing on top of three tall pillars, the statue oversees the landscape of the old Market Square of Johannesburg. The woman is carrying a child against her body, attached to her back by a blanket. It seems as if she was drawn from the far corners of rural South Africa to the middle of town to join the many other black women like her walking around Joburg carrying their kids the same way. There is something peculiar about that woman's attitude, though. On one hand, her defiant figure carries a placard where one can read the words "democracy is dialogue"; on the other, she holds a flaming Molotov cocktail..22 Ultimately, the work evokes a constitutive tension between violence, mobility, and inequality. ${ }^{23}$

The long and oftentimes violent path to democracy in South Africa is inextricably embedded in the soil where the statue stands; a history of racial segregation epitomized by the restricted access of the non-white population to the city. Representing the goddess of democracy, she is a reminder of the struggle for equal rights to all South Africans; a struggle inextricably linked to the dismounting of the three supporting pillars of the

\footnotetext{
${ }^{21}$ The racial groups in South Africa, a legacy from the apartheid era, are written in italics to stress they are being used in their native sense. It is important to emphasize that they operate in a very different way if compared to the Brazilian context; a cultural translation of those differences and their social implications, however, would require further development. Other native terminologies, informal words such as nicknames, and terms in languages other than English are also written in italics throughout the text. Concepts and categories are first cited in quotation marks, then mentioned also using italics.

${ }^{22}$ What looks pretty much like a Molotov cocktail is officially described in art reviews and news articles as a candle in a bottle. Laurence Lemaoana, the artist who conceived the sculpture, intentionally invited such ambiguity to his work. He wanted to show that the way to democracy, towards a fair and inclusive society in South Africa, was a path of struggle. Still is. South Africa is considered one of the most unequal countries in the world and the lines of social inequality are still strongly race-based. The work also has a strong gender component, as Lemaoana explains, “... [t] he work for me speaks to the idea that women in protest were not passive as characterized by popular South African history but active agents in achieving their own freedom". See Afronova n.d.

${ }^{23}$ Perennial to highly unequal post-colonial capitalist countries, this tension is increasingly relevant in the post-cold war era in the "developed world" or the so-called "global-North". The global migration flows interconnect the "global-North" and the "global-South" as people tend to move towards better life conditions, fleeing from civil wars, authoritarianism or just to be close to employment opportunities. The "migrant crisis" in Europe and the controversial "Trump wall" in the United States are remarkable examples of political exploitation of existential and material insecurities arising from the mobility of populations in the developed world. Following the lines of world inequalities drawn by colonialism, those movements are commonly associated with local issues of crime, poverty and unemployment.
} 
apartheid regime: the system of restricted circulation, the policy of forced removals and the creation of segregated areas. The imminent end of the apartheid saw those restrictions progressively lifted, officially entitling all south Africans with freedom of mobility. As a result, Johannesburg's inner city demographic profile changed from an exclusive white to a dominant black area. The struggles over the uses of the city also changed. In the postapartheid city, the woman with the Molotov cocktail in her hand would be fighting against illegal evictions and the violence of police raids. In democratic South Africa, the State can no longer prevent her from accessing the city on the basis of race. But if race is no longer a valid marker, how are the lines separating authorized and unauthorized uses of the city being drawn today?

In the $19^{\text {th }}$ century, the old Market Square in Johannesburg CBD was the epicenter of the Gold Rush, its beating financial heart in the days when the area was "net blanke" (only white). During the apartheid years, the enforcement of the segregation laws ${ }^{24}$ kept the access of other "racial groups" to the city strictly bound to their incorporation as unskilled workforce (domestic, and blue-collar workers). In the 80's, however, the intensification of the anti-apartheid protests marked an important transition in the area's demographic profile. That process - well documented in the city's historiography (Morris 1999, Van Onselen 2001, Murray and Malan 2006, Murray 2008, Harrison et al. 2010) - was caused by a massive migration of the economic axis of Johannesburg. Watching the city being encroached, the financial capital (together with the whites) migrated to the Northern suburbs of Joburg (Sandton, Rosebank, Illovo), embanked behind gated communities, electrified fences and private security guards.

Many of the inner-city buildings, now made home for a lower income black population arising from the homelands and townships, ${ }^{25}$ were soon "hijacked" by criminal syndicates and sold illegally to its actual residents. As in the case of Rio de Janeiro, those syndicates bloom in the gaps of governmental policies, counting on the connivance of corrupt government agents. Carriers of precarious legal rights, the inhabitants of those buildings struggle to make their lives viable between the arbitrariness of police raids and the violence of their illegal landlords. Their presence in the inner city, however, is not just a source of conflict and distress, but a strong conveyor of economic and political powers. Articulating new forms of spatial segregation and subaltern integration in the postapartheid era in Johannesburg, those forces end up creating restricted circulations by promoting an exclusive ideal of the city, built over an intricate discursive apparatus articulating categories like legal/illegal and safe/unsafe.

The presence of hijacked buildings is generally perceived as an indication of danger in Johannesburg inner city. In their public statements, governmental authorities commonly

\footnotetext{
${ }^{24}$ For a list of the apartheid laws from 1850 until 1970, see South African History Online n.d.

${ }_{25}$ To summarize, "city", "township" and "homelands" were the basic spatial divisions applied by the apartheid state in South Africa. The first were exclusively white, and the hub of the country's political and economic life. The townships were areas created by the state on the fringes of the city to accommodate the black and coloured populations employed at the only-white urban areas. The non-white were allowed in the city only to work and as long as they had a "pass", like an internal passport; if they were caught by the police without a pass, jail was their most likely next destination. The homelands, also known as "bantustans", were labor reserves situated far from the city. According to the apartheid ideology of "separate development", the bantustans were places of living for the non-employed black population where the "bantus" (blacks) were allowed to cultivate their "traditional ways".
} 
stress that the root-cause of the problem is "illegal migration". ${ }^{26}$ As it's well-known, the "foreigner" is commonly identified with danger, a source of instability, standing for shared fears and anxieties. In South Africa, the fear instilled by illegal migration is politically exploited by many public authorities. They blame the migrants not just for the problems taking place in Joburg, but for the endemic unemployment and violence in South Africa. Their irresponsible statements have fueled a series of xenophobic attacks, a phenomenon that often causes death and destruction of properties of many foreign nationals in the inner-city area. ${ }^{27}$

The real-estate market apparently saw real profit potential in the dodgy inner city, embarking on governmental initiatives like the CID (City Improvement Districts) ${ }^{28}$ and strategic policies like affordable housing ${ }^{29}$ to build developed urban communities. Since the early 2000s, the municipal authorities - helped by private companies, like the Red Ants $^{30}$ - have been working tirelessly on raiding and evicting the illegal occupants of the hijacked buildings in order to restore the Golden City ${ }^{31}$ to its old glorious days. We can reflect on the implications of this process operating in the so-called "New Urban Wave", a development fever that struck the central city areas in the early 2000s.

Maboneng, a precinct at the Eastern side of the CBD, in Jeppestown, was said to be the epicenter of the inner-city renaissance. This story of urban development, however, picked a not-so-bright past reference for its brand. The word Maboneng, in IsiZulu, means "the place of light". Back in Joburg's early days, that was the name given by the black migrant population coming from the distant homelands, where there was no electricity, stunned by the sight of the city illuminated by the lights of the white colonial society.

People in charge of the Maboneng project define it as a "collaborative hub of culture, business and lifestyle", a safe environment for the development of "a sense of urban togetherness". ${ }^{32}$ The place has a strong appeal to creative professionals, youth with liberal careers and recently constituted families transitioning to a more established desired Northern suburb lifestyle (Gregory 2016, Burocco 2018). Walking up Commissioner Street from Maboneng, heading the CBD, you could see the placards announcing the new real estate developments in the inner-city area. "Move In/ Move Up," it said, stamping the faces of the new urban wave (a black family with one child and

\footnotetext{
${ }^{26}$ Those migration flows to South Africa - coming from all Africa, but mostly from its Southern part - are motivated by tribal violence and civil wars, but also the search for better economic conditions. For more information, see Mercandalli and Losch 2017. See also DeJesus 2018. For more about the so-called "illegal migrants" living conditions in Johannesburg inner city, see the documentary Into the Shadows: Inside Johannesburg's Underworld (2018). See also Zulu and Wilhelm-Solomon 2015 and Fassin et al. 2017.

${ }^{27}$ For more information about the recent attack in Joburg CBD, see Burke 2019.

${ }^{28}$ More information about the legal framework for this self-governed communities of urban development in the City Improvement District Act and in the website of the Johannesburg GPMA Forum https://www.gpma.co.za/legal-library/ [Access 29 March 2021].

${ }^{29}$ For more about the affordable housing projects in Joburg inner city check the African Housing Company website, a public company owned by the City of Johannesburg (https://www.afhco.co.za/; access 29 March 2021).

${ }^{30}$ For more about the Red Ants, check the amazing investigative article produced by The Guardian, 'We are a family' - on patrol with the Red Ants (Burke 2018).

${ }^{31}$ As the city of Johannesburg is also known; as a nickname, it will be graphed in italics like Joburg, short for Johannesburg.

${ }^{32}$ For more information see http://www.mabonengprecinct.com/ [access 29 March 2021].
} 
a stylish young black man), clearly associating movements in space as indexes of social ascension. Once restricted as "whites only", the new urban wave of today is mainly black, with its welcome and unwelcome inhabitants (Albernaz 2018, 33-40).

If, in Brazil, we blame the "absence" of the State as the main issue affecting the lives of the popular classes and their places of living, in Joburg the perception is of an "inability" of the black majority government to deal with the problems affecting major South African cities. The latest local elections, in 2016, have cost the ANC (African National Congress) ${ }^{33}$ the government of the Johannesburg municipality. The Democratic Alliance (DA) ${ }^{34}-\mathrm{a}$ party known as a representative of the so-called "white monopoly capital", messenger of a "managerial" neoliberal approach of the State - won the municipal elections led by a black candidate, Herman Mashaba. Mashaba's victory can be partially understood as an electoral reflection of the anxieties and social mobility expectations of a growing black middle class in South Africa. ${ }^{35}$ A generation of "born free" college students, young professionals and recently established families; people that only know about the harder years of the apartheid ${ }^{36}$ regime from books, inhabiting Joburg's inner city and scared by the proximity with extreme levels of poverty and crime.

Those new urban developments, like Maboneng, undeniably represent progress. They are diverse, affordable and culturally vibrant places where a growing young black middle class can start paving its way to the more affluent Northern suburbs, materializing expectations of social and spatial mobility (Southall 2016). The alleged benefits of those new developments, however, obfuscate the conservative nature of some of their outcomes. Very dependent on governmental influence, those discontinuities on the urban fabric are not just propelled by powerful market forces, but are actively led by them. They are also casting a giant shadow of public virtues over the economic interests involved in developments like the new urban wave, opening Joburg inner city for business again while pushing the problem represented by that impoverished black population back to its margins, compromising dramatically (sometimes, permanently) their own material existence. ${ }^{37}$

\section{3. "Persistent precariousness" and the possibility of real democracy}

Inspired by the iconic image of the Greek Polis, the "city" has been traditionally associated with the free exchange of ideas and the manifestation of differences. The Greek city was also the birthplace of one crucial character to the political history of the West: the "citizen", the most celebrated inhabitant of the polis. In the spaces of collective participation, all Greek citizens were seen as equals. The ideal of equality, however, to be operative of a certain citizenship, had to have its limits clearly established. Who is allowed to participate in the sovereign community of citizens? Who can be an accredited voice in the polis?

\footnotetext{
${ }^{33}$ For more information https://www.sahistory.org.za/article/african-national-congress-anc [access 29 March 2021].

${ }^{34}$ For more information https://www.sahistory.org.za/article/democratic-alliance-da [access 29 March 2021].

${ }^{35}$ About that, see the illustrative discussion of Nkateko Mabasa (2019).

${ }^{36}$ Meaning "separation" in Afrikaans.

${ }^{37}$ See article of the independent news agency Elitsha (Sehoai 2017) Evictions in central Joburg leave families stranded about the massive eviction operation in the Fattis Mansions in 2017, a symbol of the struggle for space in Joburg CBD.
} 
The Greek concept of citizenship excluded from the public arenas and spaces of politics women, children and slaves. ${ }^{38}$ Modern democracies, heirs to those ideals, are formal tributaries of the idea of equal rights as a founding dimension of citizenship. The degrading living conditions of ever-increasing segments of their population and the unaccounted violation of their legal rights unequivocally show, however, that "citizenship" is a rare political asset, unevenly distributed over the nation-state territory. In fact, the full realisation of those enlightened ideals of equality in the capitalist democracies of our days is being actively challenged everywhere, by scholars, by recent events of political history, or simply by the everyday of those not partaking in the benefits of economic development.

According to Partha Chatterjee (2004), the "democratic State" should not be approached by social researchers as a given reality. What the author calls the "practical helms of citizenship", therefore, would emerge from the observation of localized governance techniques, developed in direct contact with people living on the fringes of enclavities of law and order in India society (the "governed"). For Veena Das and Debora Poole (2004), the "margins of State" are also privileged places to observe the practical limits of the democratic ideals. For the authors, the discursive production of the margins as the outskirts of the political order is actually a strong conveyer of political powers. In Brazil, authors like Roberto Kant de Lima show the operation of the judicial system actively producing distinctions in the citizenship status of segments of the population (Lima 1997, 2001, Amorim et al. 2005). Sampie Terreblanche (2002) talks about compromises between a mainly white global corporate sector and the new black governing elite promoting the systemic exclusion of the black majority from the benefits of economic development and democracy in the post-apartheid South Africa. ${ }^{39}$

Besides their similar approach to "formal democracy", almost as a political chimera, the works cited above and many others (Wacquant 2008, Comaroff and Comaroff 2016, Goffman 2015; among other) highlight the multifaceted relationship between the State and its many margins in the reproduction of political power and economic domination in formally democratic societies. Departing from a Brazilian research background, ${ }^{40}$ in

\footnotetext{
38 The ones entitled to a public voice, the members of "civil society", had also to match income criteria and to have the right body heat, once the body temperature was seen as an inductor of cognitive and speech capacities. Foreigners also had no right to political life in the city, once "territory" and "citizenship" (and, therefore, "sovereignty") were associated concepts in the Greek Polis (Sennett 2003).

${ }^{39}$ The author - quoting Tabo Mbeki, South Africa's President after Nelson Mandela - affirmed that the country, after eight years of democracy, was living under a new "global-apartheid", with the systematic "peripheralisation" and "casualization" of black labour, and the formation of what he called "first world capitalist enclavities" (Terreblanche 2002, 434)

${ }^{40}$ The analyses drafted here conform to an initial statement for a research program being built by the Laboratory of Studies on Conflict, Citizenship and Public Security (Laesp/UFF) in partnership with the Witwatersrand University (WITS) in Johannesburg; for that, we thank Prof. Julia Hornberger and Dr. Matthew Wilhelm-Solomon from WITS Anthropology Department. They are based on our work, on the work of other Laesp researchers as well as on the long history of comparative interdisciplinary research that lies behind it. For this group, the observation of urban itineraries is key to unveiling the everyday mechanics of historically constituted systems of inequality and power mining the possibility of real democracy. In the following pages, we also promote a dialogue between Brazilian research and the South African bibliography about the recent changes in the old apartheid territorial divisions, happening specifically in Johannesburg. The lively discussions about Joburg CBD and the development projects in the inner city are based on the
} 
the present article, we introduce the idea of "persistent precariousness" as a possible analytical-key to explore this intricate relationship between marginal processes of State formation and statal production of the margins in Rio de Janeiro and Johannesburg. In both cases, the State is a central actor, even in its alleged "absence", or "inaptitude".

According to Pires (2017a, 2017b), the State in Brazil actively produces precarious legal bonds with subjects that are seen as entitled with a degraded "moral substance" (Oliveira 2002), engaging in exceptional regulatory regimes based on the systematic distrust on their capacity to keep mandatory bonds and honor their contracts. The Brazilian legal system has a name for that, "precarious authorization", a discretionary and unilateral act by which the State consents to the practice of individual activity on a public area/ equipment. Excluded from their access to property, those "unreliable" segments of society are subjected to the arbitrariness of state agents, authorized to revoke their precarious legal rights in the name of a vague and many times dubious ideal of "public interest". The resort to violence against those subjects is also highly accepted. This is the case, for example, of "informal" traders, or people occupying land based on precarious legal bonds.

The idea of persistent precariousness, therefore, results from systematic political actions, rooted in the organization of the legal-juridic order of the State itself, aimed at actively discrediting segments of the population, and avoiding the institution of egalitarian and universal rights. Although it's clear that those developments are symptoms of the neoliberal times, therefore, widely disseminated in the "global cities" of our days (Sassen 1991), we argue that in postcolonial countries like Brazil and South Africa they assume specific tones.

Operating at the intersection of power relations and cultural values, the production of persistent precariousness highlights the institutionalization of prejudices directed at subordinate populations, which, in Brazil and South Africa, was based on the alleged scientificity of racism that found the object of their disregard in black and mixed-race populations. Associated with the violent reorganization of the illegal exploitation of legal markets and illegalities by the State itself in Rio de Janeiro, those political actions, aiming to immobilize "undesirable" populations, are promoting powerful market forces in Johannesburg.

\section{Conclusion}

Is it possible to devise the possibility of "real democracy" without approaching the thorny subject of wealth distribution? In the present article, we argue that people's mobility can be a good methodological and analytical key to approaching complex phenomena as the perpetuation of long-term structures of social inequalities.

Pursuing the broader political effects of the relationship between violence, mobility and inequality in Brazil and South Africa, we've explored three interconnected processes: the discursive economies justifying the actions of official agencies against specific segments of the urban population; the nature of the conflicts related to social and spatial mobility in both contexts; and, finally, the grounded processes of "State formation" emerging

field work of Elizabete Albernaz for her PhD in Anthropology, conducted at the Maboneng district (Albernaz 2018). 
from the everyday administration of those conflicts. By contrastively comparing the cases, we aim to consolidate a "southern" perspective to the discussions addressing the characteristics of neoliberalism in contemporary capitalist democracies, partially illuminating complex social processes reproducing long-term inequalities by promoting a discontinuous experience of the urban space, based in the constructed oppositions between safe/unsafe and legal/illegal.

The term "neoliberal" is widely used to describe the multiplicity of policy shifts that have taken place over the last thirty years, with a common assumption that states have been "hollowed out" and turned into residual institutions with little functional power. What more spatialized analyses reveal, however, is that the alleged symptoms of its dissolution are, in fact, reflections of changes in the cultural grounds of "state formation". A process, we argue, key to understanding the production of a highly militarized and discontinuous social landscape, characterized by artificial paradises of safety and restricted circularities in the southern hemisphere.

In Joburg, we tried to highlight the role of social mobility and class aspirations as powerful political vehicles for neoliberal markets reissuing old apartheid social and spatial divisions. In Rio de Janeiro, we've explored the intricate relationship between the State and its margins to understand the historical production of the milícia as a violent anti-modern capitalist venture. What the examination of the Maboneng case has shown us is that the threat represented by the ontological uncertainties produced by crime and unemployment, embodied in the image of the illegal migrant, served as a vector to the installation of a liberal market, sheltered by governmental policies of "urban development". The operation of those markets (real estate, private security, eviction companies) produces Maboneng as a developed segregated space, a "place of light" delineated by the shadows it projects around itself.

In the case of Rio de Janeiro, we observed the exact opposite. The shadows covering the everyday in favelas like Muzema, concealing the struggles of their inhabitants, are projected by the lights of a public exposure associated with urban violence and the "mediation" (Chatterjee 2004) of local politicians, many times sponsored by the milícia itself. In those areas, the political economies producing persistent precariousness seem to work to prevent, instead of favoring, the establishment of a liberal market, articulating in its place what Albernaz (2018) called "markets of exclusion", violent, regulated and operated directly by State agents. We argued that the operation of a discursive apparatus producing persistent precariousness in the citizenship status of the subjects can partially explain the underlying mechanics of the phenomenon in both contexts.

\section{References}

Abrams, P., 1988. Notes on the difficulty of studying the state. Journal of Historical Sociology, 1(1), 58-89.

Afronova, no date. Democracy is dialogue. Afronova [online]. Available from: https://www.afronova.com/news/democracy-is-dialogue/ [Access 31 January 2020].

Aguero, G.H., and Perelman, M.D., 2019. Desigualdad, imaginarios y escala urbana. Un estudio comparativo de grupos subalternos en Salta y Buenos Aires, 
Argentina. In: P.Vera, A. Gravano and F. Aliaga, eds., Ciudades (in)descifrables imaginarios y representaciones sociales de lo urbano [online]. Bogotá: Universidad Santo Tomás. Available from: https://doi.org/10.2307/j.ctvr33dsp [Access 31 August 2021].

Albernaz, E., 2018. Palácios sem reis, democracias sem cidadãos: política, cotidiano e a formação de mercados da exclusão em dois contextos do "sul-global". Tese de Doutorado defendida no Programa de Pós-Graduação em Antropologia. Nitéroi: Universidade Federal Fluminense (PPGA/UFF).

Alfaya, I., 2019. Prédios desabam em comunidade na zona oeste do Rio de Janeiro. R7 [online], 12 April. Available from: https://noticias.r7.com/rio-de-janeiro/prediosdesabam-em-comunidade-na-zona-oeste-do-rio-de-janeiro-12042019 [Access 29 March 2021].

Alves, J.C.S., 2003. Dos barões ao extermínio: Uma história da violência na Baixada Fluminense. Duque de Caxias: Associação de Professores e Pesquisadores de História, CAPPH-CLIO.

Alves, J.C.S., 2008. Milícias: mudanças na economia política do crime no Rio de Janeiro. In: Justiça Global, ed., Segurança, tráfico e milícias no Rio de Janeiro [online]. Rio de Janeiro: Fundação Heinrich Böll, pp. 33-36. Available from: http://www.dhnet.org.br/dados/relatorios/r jglobal/r jg rj milicias.pdf [Access 31 August 2021].

Amar, P., 2013. The security archipelago. Duke University Press.

Amorim, M.S. de, Lima, R.K. de, and Mendes, R.L.T., 2005. Ensaios sobre a igualdade jurídica: Acesso à justiça criminal e direitos de cidadania no Brasil. Rio de Janeiro: Lumen Juris.

Appadurai, A., 2001. La modernidad desbordada. Buenos Aires: Trilce/ Fondo de Cultura Económica.

Bayat, A., 2000. From Dangerous Classes' to Quiet Rebels' Politics of the Urban Subaltern in the Global South. International sociology, 15(3), pp. 533-557.

Bell, D.A., and De-Shalit, A., 2013. The spirit of cities. Princeton University Press.

Benjamin, C., et al., 1998. A opção brasileira. Rio de Janeiro: Contraponto.

Burke, J., 2018. "We are a family" - on patrol with the Red Ants. The Guardian [online], 8 May. Available from: https://www.theguardian.com/world/nginteractive/2018/may/08/red-ants-mass-evictions [Access 29 March 2021].

Burke, J., 2019. “We are a target": wave of xenophobic attacks sweeps Johannesburg. The Guardian [online], 10 September. Available from: https://www.theguardian.com/world/2019/sep/10/we-are-a-target-wave-ofxenophobic-attacks-sweeps-johannesburg [Access 29 March 2021].

Burocco, L., 2018. Pólos criativos de colonialidad no sul (Creative hubs of coloniality in the South). Tese de Doutorado. Universidade Federal do Rio de Janeiro, Escola de Comunicação, Programa de Pós-Graduação em Comunicação e Cultura. 
Caldeira, T.P., 1997. Enclaves fortificados: A nova segregação urbana. Novos estudos [online], v. 47, pp. 155-76. Available from: https://liquefeito.com.br/ippur/images/Texto 2 CALDEIRA Teresa P. do R. Enclaves fortificados segrega $\% \mathrm{C} 3 \% \mathrm{~A} 7 \% \mathrm{C} 3 \% \mathrm{~A} 30$ urbana.pdf [Access 31 August 2021].

Caldeira, T.P., 2000. Cidade de muros: Crime, segregação e cidadania em São Paulo. São Paulo: Editora 34.

Cano, I., and Duarte, T., 2012. No sapatinho: A evolução das milícias no Rio de Janeiro (2008-2011). Rio de Janeiro: Laboratório de Análise da Violência (LAV) da Universidade do Estado do Rio de Janeiro (UERJ)/Fundação Heinrich Böll.

Carraro, V., 2019. Grounding the digital: a comparison of Waze "avoid dangerous areas" feature in Jerusalem, Rio de Janeiro and the US. GeoJournal [online]. Available from: https://doi.org/10.1007/s10708-019-10117-y [Access 29 March 2021].

Chatterjee, P., 2004. The politics of the governed: Reflections on popular politics in most of the world. New York: Columbia University Press.

Comaroff, J., and Comaroff, J.L., 2016. The truth about crime: Sovereignty, knowledge, social order. University of Chicago Press.

Da Silva, G., 2019. “Quantos ainda vão morrer, eu não sei”: O regime do arbítrio, da curtição, morte e a vida em um lugar chamado de favela. Tese de doutorado. Niterói: PPSD/Universidade Federal Fluminense.

Das, V., and Poole, D., 2004. Anthropology in the Margins of the State. PoLAR: Political and Legal Anthropology Review [online], 30(1), pp. 140-144. Available from: https://doi.org/10.1525/pol.2007.30.1.140 [Access 31 August 2021].

Das, V., and Randeria, S., 2015. Politics of the urban poor: aesthetics, ethics, volatility, precarity: An introduction to supplement 11. Current Anthropology [online], 56(S11), pp. S3-S14. Available from: https://doi.org/10.1086/682353

DeJesus, K.M., 2018. Forced migration and displacement in Africa: contexts, causes and consequences. African Geographical Review, 37(2), pp. 29-82.

Dias, J.B., Thomaz, O.R., and Filho, W.T., 2008. Brazilian Anthropologists in Africa. Remarks on Theory, Politics and Fieldwork Overseas. VIBRANT-Vibrant Virtual Brazilian Anthropology [online], 5(2), pp. 277-303. http://www.redalyc.org/articulo.oa?id=406941906013 [Access 31 August 2021].

Eriksen, T.H., 2014. Globalization: The key concepts. London: A\&C Black.

Faoro, R., 2008. Os donos do poder: Formação do patronato político brasileiro. Rio de Janeiro: Biblioteca Azul. (Originally published in 1958).

Farias, J., et al., 2020. Militarização no Rio de Janeiro: Da pacificação à intervenção. Rio de Janeiro: Mórula.

Fassin, D., Wilhelm-Solomon, M., and Segatti, A., 2017. Asylum as a Form of Life. Current Anthropology, 58(2), pp. 160-176. 
Ferguson, J., 2006. Global shadows: Africa in the neoliberal world order. Durham: Duke University Press.

Ferguson, J., 2014. Transnational topographies of power: beyond "the State" and "civil society" in the study of African politics. Occasional paper [online], 19, pp. 45-71. Available from: https://ojs.ruc.dk/index.php/ocpa/article/view/3815 [Access 31 August 2021].

Ferguson, J., and Gupta, A., 2002. Spatializing states: toward an ethnography of neoliberal governmentality. American Ethnologist, 29(4), pp. 981-1002.

Filho, W.T., and Dias, J.B., 2015. O colonialismo em África e seus legados: classificação e poder no ordenamento da vida social. Anuário Antropológico [online], 40(2), pp. 9-22. Available from: https://doi.org/10.4000/aa.1371 [Access 31 August 2021].

Fórum Brasileiro de Segurança Pública, 2021. Anuário Brasileiro de Segurança Pública [online]. Last updated 15 July. Available from:

https://forumseguranca.org.br/anuario-brasileiro-seguranca-publica/ [Access 29 March 2021].

Foucault, M., 1979. Microfísica do poder. Rio de Janeiro: Graal.

Foucault, M., 1984. História da sexualidade I: A vontade de saber. Trans: M.T. de C. Albuquerque and J.A.G. Albuquerque. Rio de Janeiro: Graal.

Foucault, M., 2001. Vigiar e punir. Trans.: R. Ramalhete. Petrópolis: Vozes.

Foucault, M., 2007. Territory, Security, Population: Lectures at the Collège De France 19771978. Trans.: G. Burchell. London: Palgrave Macmillan.

Geertz, C., 2003. Le Souk de Sefrou: Sur l'économie du bazar. Trans.: D. Cefaï. Saint-Denis: Bouchene.

Gennari, A.M., 2002. Globalização, neoliberalismo e abertura econômica no Brasil nos anos 90. Pesquisa \& Debate: Revista do Programa de Estudos Pós-Graduados em Economia Política [online], 13(1[21]). Available from: https://revistas.pucsp.br/rpe/article/view/12029 [Access 31 August 2021].

Goffman, A., 2015. On the run: Fugitive life in an American city. London: Picador.

Graham, S., 2011. The new military urbanism. In: G. Bridge and S. Watson, eds., The New Blackwell Companion to the City. Hoboken: Blackwell, pp. 121-133.

Gregory, J.J., 2016. Creative industries and urban regeneration-The Maboneng precinct, Johannesburg. Local Economy, 31(1-2), pp. 158-171.

Guha, R., and Spivak, G.C., eds., 1988. Selected subaltern studies. Oxford University Press.

Guimarães, A., Leitão, L., and Martins, M.A., 2019. Operação prende 13 suspeitos de investir em imóveis da milícia na Muzema, no Rio. Globo [online], 16 July.

Available from: https://g1.globo.com/rj/rio-dejaneiro/noticia/2019/07/16/operacao-tenta-prender-investidores-e-responsaveispor-imoveis-da-milicia-na-muzema-no-rio.ghtml [Access 29 March 2021]. 
Hannerz, U., 1980. Exploring the city: Inquiries toward an urban anthropology. New York: Columbia University Press.

Harrison, P., et al., 2010. Changing Space, Changing City: Johannesburg after apartheid. Johannesburg: Witwatersrand University Press.

Holanda, S.B. de, 1976. Raízes do Brasil. $9^{\text {th }}$ ed. Rio de Janeiro: José Olympio.

Hollington, A., et al., 2015. Concepts of the Global South. Cologne: Global South Studies Center.

Instituto Brasileiro de Geografia e Estatística (IBGE), 2010. Censo [online]. Available from: http://www.censo2010.ibge.gov.br/ [Access 29 March 2021].

Into the Shadows: Inside Johannesburg's Underworld (Crime Documentary), 2018. YouTube clip. Real Stories [online], 24 March. Available from: https://www.youtube.com/watch?v=mkaWctIgjtc [Access 29 March 2021].

Krader, L., 1970. A formação do estado. Rio de Janeiro: Jorge Zahar.

Krohn-Hansen, C., and Nustad, K.G., eds., 2005. State formation: Anthropological perspectives. London: Pluto Press.

Landau, L.B., 2007. Discrimination and development? Immigration, urbanisation and sustainable livelihoods in Johannesburg. Development Southern Africa, 24(1), pp. 61-76.

Lefebvre, H., 1991. O direito à cidade. São Paulo: Moraes. (Originally published in 1968).

Lefebvre, H., 1999. A revolução urbana. Belo Horizonte: UFMG. (Originally published in 1970).

Leite, M.P., 2012. Da "metáfora da guerra" ao projeto de "pacificação": Favelas e políticas de segurança pública no Rio de Janeiro. Revista Brasileira de Segurança Pública [online], 6(2). Available from:

https://revista.forumseguranca.org.br/index.php/rbsp/article/view/126/123 [Access 31 August 2021].

Leite, M.P., 2014. Entre a "guerra" e a "paz": Unidades de Polícia Pacificadora e gestão dos territórios de favela no Rio de Janeiro. Dilemas-Revista de Estudos de Conflito e Controle Social, 7(4), pp. 625-642.

Lemanski, C., 2004. A new apartheid? The spatial implications of fear of crime in Cape Town, South Africa. Environment and Urbanization, 16(2), pp. 101-112.

Lima, A.C. de S., 2010. Poder tutelar y formación del Estado en Brasil: notas a partir de la creación del Servicio de Protección a los Indios y Localización de Trabajadores Nacionales. Desacatos [online], 33, pp. 53-66. Available from:

https://doi.org/10.29340/33.354 [Access 31 August 2021].

Lima, A.C. de S., 2012. Apresentação. Revista de Antropologia [online], 55(2), pp. 559 564. Available from: https://www.revistas.usp.br/ra/article/download/59295/64154 [Access 31 August 2021]. 
Lima, R.K. de, 1997. Polícia e exclusão na cultura judiciária. Tempo Social [online], 9(1), pp. 169-183. Available from: https://doi.org/10.1590/S0103-20701997000100009 [Access 31 August 2021].

Lima, R.K. de, 2001. Administração de conflitos, espaço público e cidadania: uma perspectiva comparada. Civitas-Revista de Ciências Sociais [online], 1(2), pp. 11-16. Available from: https://doi.org/10.15448/1984-7289.2001.2.73 [Access 31 August 2021].

Lima, R.K. de, Eilbaum, L., and Medeiros, F.S., eds., 2017. Casos de repercussão: perspectivas antropológicas sobre rotinas burocráticas e moralidades. Rio de Janeiro: Consequência.

Mabasa, N., 2019. As I experience class mobility, will I protect my interests like the DA's black middle class? Daily Maverick [online], 23 April. Available from: https://www.dailymaverick.co.za/opinionista/2019-04-23-as-i-experience-classmobility-will-i-protect-my-interests-like-the-das-black-middle-class/ [Access 29 March 2021].

Marcus, G.E., 1995. Ethnography in/of the world system: The emergence of multi-sited ethnography. Annual review of anthropology, 24(1), pp. 95-117.

Marés, C., Resende, L., and Afonso, N., 2018. CPI das Milícias: o que ocorreu com os políticos citados no relatório? Lupa [online], 12 May. Available from: https://piaui.folha.uol.com.br/lupa/2018/05/12/cpi-milicias-politicos/ [Access 29 March 2021].

Marshall, A., 2016. Crime Alerts Come to Brazilian Waze, Just in Time for the Olympics. Wired [online], 31 July. Available from: https://www.wired.com/2016/07/crime-alerts-come-brazilian-waze-just-timeolympics/[Access 29 March 2021].

Martín, M., 2015. Mulher morre baleada ao entrar por engano em uma favela no Rio [Woman dies by mistake when entering a favela in Rio]. El País [online], 6 October. Available from: https://brasil.elpais.com/brasil/2015/10/05/actualidad/1444062892 524126.html [Access 29 March 2021].

Mbembe, A., 2019. Necropolitics. Durham: Duke University Press.

Medeiros, F., 2017. A necropolítica da "guerra": tecnologias de governo, "homicídios" e "tráfico de drogas" na região metropolitana do Rio de Janeiro. Abya-Yala: Revista sobre acesso à justiça e direitos nas Américas [online], 1(3), pp. 73-94. Available from: https://doi.org/10.26512/abyayala.v1i3.7119 [Access 31 August 2021].

Medeiros, F., 2018. O morto no lugar dos mortos: classificações, sistemas de controle e necropolítica no Rio de Janeiro. Revista $M$ [online], 3(5), pp. 72-91. Available from: https://doi.org/10.9789/2525-3050.2018.v3i5.72-91 [Access 31 August 2021].

Melber, H., ed., 2016. The Rise of Africa's Middle Class: Myths, realities and critical engagements [online]. London: Zed Books. Available from: https://doi.org/10.5040/9781350251168 [Access 31 August 2021]. 
Mello, M.A. de S., and Silva, L.M. da, 2012. Favelas cariocas ontem e hoje. Cadernos carioca [online], 22(22). Available from: https://doi.org/10.11606/issn.23169133.v22i22p352-357 [Access 31 August 2021].

Menezes, P.V., 2018. Monitorar, negociar e confrontar: As (re) definições na gestão dos ilegalismos em favelas "pacificadas". Tempo Social [online], 30(3), pp. 191-216. Available from: https://doi.org/10.11606/0103-2070.ts.2018.133202 [Access 31 August 2021].

Mercandalli, S., and Losch, B., eds., 2017. Rural Africa in motion. Dynamics and drivers of migration South of the Sahara [online]. Rome: FAO/CIRAD. Available from: http://www.fao.org/3/I7951EN/i7951en.pdf [Access 29 March 2021].

Misse, M., 2008. Sobre a acumulação social da violência no Rio de Janeiro. Civitas, Porto Alegre [online], 8(3), pp. 371-385. Available from: https://core.ac.uk/download/pdf/25530734.pdf [Access 31 August 2021].

Misse, M., 2010. Trocas ilícitas e mercadorias políticas: para uma interpretação de trocas ilícitas e moralmente reprováveis cuja persistência e abrangência no Brasil nos causam incômodos também teóricos. Anuário Antropológico [online], 35(2), 98 107. Available from: https://doi.org/10.4000/aa.916 [Access 31 August 2021].

Mitlin, D., and Satterthwaite, D., 2013. Urban Poverty in the Global South: Scale and Nature. London: Routledge.

Morris, A., 1999. Bleakness \& light: Inner-city transition in Hillbrow, Johannesburg. Johannesburg: Witwatersrand University Press.

Murray, M.J., 2008. Taming the disorderly city: The spatial landscape of Johannesburg after apartheid. Ithaca: Cornell University Press.

Murray, M.J., and Malan, J., 2006. Photographic Essay: Johannesburg Fortified. In: M.J. Murray and G. Myers, eds., Cities in Contemporary Africa: Place, Politics, and Livelihood. New York: Palgrave Macmillan, pp. 95-101.

Nelson, J.M., 2017. Access to power: Politics and the urban poor in developing nations. Princeton University Press.

O Globo and Extra, 2006. Milícias expulsam os traficantes de drogas e já controlam 92 favelas da cidade. O Globo [online], 9 December. Available from: https://oglobo.globo.com/rio/milicias-expulsam-os-traficantes-de-drogas-jacontrolam-92-favelas-da-cidade-4541224 [Access 29 March 2021].

Oliveira, L.R.C., 2002. Direito legal e insulto moral - dilemas da cidadania no Brasil, Quebec e EUA. Rio de Janeiro: Relume-Dumará.

Omena de Melo, E.S., 2017. Exerting State Power in Core and Semi-peripheral Countries: Land Clearance and Domination Strategies in London, Rio de Janeiro and Johannesburg. Dissertation, Doctor of Philosophy. Oxford Brookes University.

Park, R., 1979. A cidade: sugestões para investigação social no meio urbano. In: O.G. Velho, ed., O fenômeno urbano. Rio de Janeiro: Zahar.

Pauw, B.A., 1962. The second Generation. Cape Town: Oxford University Press.

Piketty, T., 2014. Capital in the $21^{\text {st }}$ Century. Harvard University Press. 
Pillay, S., 2008. Crime, community and the governance of violence in post-apartheid South Africa. Politikon [online], 35(2), pp. 141-158. Available from: https://doi.org/10.1080/02589340802366943 [Access 31 August 2021].

Pinker, S., 2018. Enlightenment Now: The case for reason, science, humanism and progress. New York: Penguin Random House.

Pinnock, D., 2016. Cape Town: Gang town. Cape Town: Tafelberg.

Pires, L., 2011. Esculhamba, mas não esculacha! Uma etnografia dos usos urbanos dos trens da Central do Brasil [online]. Niterói: EDUFF. Available from:

http://www.eduff.uff.br/index.php/livros/173-esculhamba-mas-nao-esculachauma-etnografia-dos-usos-urbanos-dos-trens-da-central-do-brasil [Access 31 August 2021].

Pires, L., 2017a. Limites e Desafios de um mundo sob o signo da precariedade. Antropolitica [online], 43, pp. 283-293. Available from: https://doi.org/10.22409/antropolitica2017.0143.a41770 [Access 31 August 2021].

Pires, L., 2017b. Precários e perigosos: possíveis relações entre formalidade e informalidade em processos de administração de conflitos no Rio de Janeiro. In: J. Gledhill, M.G. Hita and M. Perelman, eds., Disputas em torno do espaço urbano: processos de [re] produção/construção e apropriação da cidade. Bahía: EDUFBA.

Pires, L., 2019. Transportes públicos, cidadania e política: Grandes eventos e "globatização" no Rio de Janeiro. Dilemas, 8(3), pp. 11-28.

Pires, L., Hirata, D.V., and Maldonado, S.A., 2020. Mercados populares, ilegalismos e suas regulações pela violência. Antropolitica [online], 50. Available from: https://doi.org/10.22409/antropolitica2020.i50.a47749 [Access 31 August 2021].

Preteceille, E., and Valladares, L., 2000. Favela, favelas: Unidade ou diversidade da favela carioca. O futuro das metrópoles. Río de Janeiro: Revan.

Resende, L., 2019. Mesmo preso, miliciano que controla Muzema foi convidado a evento da PM. Veja [online], 20 April. Available from:

https://veja.abril.com.br/brasil/mesmo-preso-miliciano-que-controla-muzema-foiconvidado-a-evento-da-pm/ [Access 29 March 2021].

Ribeiro, G.L., et al., eds., 2015. Social, political and cultural challenges of the BRICS [online]. São Paulo: ANPOCS. Available from:

http://anpocs.com/images/stories/Geral/encontrosanuais/37eaa/BRICS.pdf [Access 31 August 2021].

Ribeiro, L.C., and Santos Junior, O.A. dos, 2017. Neoliberalization and mega-events: The transition of Rio de Janeiro?s hybrid urban order. Journal of Urban Affairs [online], 39(7), pp. 909-923. Available from: https://doi.org/10.1080/07352166.2017.1328976 [Access 31 August 2021].

Rodrigues, A., et al., 2018. Homicídios na Baixada Fluminense: Estado, mercado, criminalidade e poder. Comunicações ISER [online], 71, ano 37. Available from: http://www.iser.org.br/site/wp-content/uploads/2013/12/2018-08-06-publicacao71iser-WEB.pdf [Access 31 August 2021]. 
Rosling, H. (with O. Rosling and A.R. Rönnlund), 2019. Factfulness: Ten reasons we're wrong about the world - and why things are better than we think. London: Sceptre Books.

Sánchez, F., and Broudehoux, A.M., 2013. Mega-events and urban regeneration in Rio de Janeiro: planning in a state of emergency. International Journal of Urban Sustainable Development, 5(2), pp. 132-153.

Santos, B. S., 2002. Para uma sociologia das ausências e uma sociologia das emergências. Revista Crítica de Ciências Sociais, Revista Crítica de Ciências Sociais Coimbra, n. 63, out., p. 237-280.

Sassen, S., 1991. The Global City: New York, London and Tokyo. Princeton University Press.

Sehoai, R., 2017. Evictions in central Joburg leave families stranded. Elitsha [online], 18 August. Available from: https://elitshanews.org.za/2017/08/18/evictions-incentral-joburg-leave-families-stranded/ [Access 29 March 2021].

Sennett, R., 2003. Carne e pedra: O corpo e a cidade na civilização ocidental. Trans.: M.A. Reis. Rio de Janeiro: Record.

Sharma, A., 2006. Introduction: Rethinking theories of the state in an age of globalization. Division II Faculty Publications, p. 42.

Shermer, M., 2015. The Moral Arc: How science and reason led humanity towards truth, justice and reason. New York: Macmillan USA.

Silva, L.A.M. da, 2004. Sociabilidade violenta: por uma interpretação da criminalidade contemporânea no Brasil urbano. Sociedade e estado [online], 19(1), pp. 53-84. Available from: https://doi.org/10.1590/S0102-69922004000100004 [Access 31 August 2021].

Silva, L.A.M. da, 2008. Vida sob cerco: Violência e rotina nas favelas do Rio de Janeiro. Rio de Janeiro: Nova Fronteira.

South African History Online (SAHO), no date. Apartheid Legislation 1850s-1970s [online]. Johannesburg: SAHO. Available from: https://www.sahistory.org.za/article/apartheid-legislation-1850s-1970s [Access 29 March 2021].

Southall, R., 2016. The new black middle class in South Africa. Suffolk/Rochester: Boydell \& Brewer.

Spinks, C., 2001. A new apartheid?: Urban spatiality,(fear of) crime, and segregation in Cape Town, South Africa [online]. London School of Economics and Political Science, Development Studies Institute. Available from: https://www.files.ethz.ch/isn/138143/WP20.pdf [Access 31 August 2021].

Spivak, G.C., 2010. Pode o subalterno falar? $1^{\text {st }}$ ed. Trans. S.R.G. Almeida, M.P. Feitosa and A. Pereira. Belo Horizonte: UFMG.

Terreblanche, S., 2002. A history of inequality in South Africa, 1652-2002. Durban: University of Kwazulu Natal Press. 
Thévenot, L., 2006. L'action au pluriel: sociologie des régimes d'engagement. Paris: La Découverte.

Trouillot, M.R., 2001. The anthropology of the state in an age of globalization: Close encounters of a deceptive kind. Current Anthropology, 42(1), pp. 125-138.

Van Onselen, C., 2001. New Babylon, New Nineveh: Everyday Life on the Witwatersrand, 1886-1914. Jeppestown: Jonathan Ball.

Van Onselen, C., 2019. The seed is mine: The life of Kas Maine, a South African sharecropper 1894-1985. Jeppestown: Jonathan Ball.

Van Onselen, C., 2021. The Night Trains: Moving Mozambican Miners to and from the Witwatersrand Mines, 1902-1955. Oxford University Press.

Virilio, P., 1986. Speed and Politics: An Essay on Dromology. Trans.: M. Polizzotti. New York: Semiotext(e). (Originally published in French in 1977).

Wacquant, L., 2008. Urban outcasts: A comparative sociology of advanced marginality. Cambridge/Oxford/Boston/New York: Polity.

Werneck, A., and De Souza, R.N., 2019. Narcomilícias: traficantes e milicianos se unem em 180 áreas do Rio, segundo investigação. O Globo [online], 10 October.

Available from: https://oglobo.globo.com/rio/narcomilicias-traficantes-milicianosse-unem-em-180-areas-do-rio-segundo-investigacao-24007664 [Access 29 March 2021].

Wilhelm-Solomon, M., 2020a. Johannesburg cannot police its future. Mail \& Guardian [online], 27 October. Available from: https://mg.co.za/coronavirusessentials/2020-10-27-johannesburg-cannot-police-its-future/ [Access 29 March 2021].

Wilhelm-Solomon, M., 2020b. The City Otherwise: The Deferred Emergency of Occupation in Inner-City Johannesburg. Cultural Anthropology [online], 35(3), pp. 404-434. Available from: https://doi.org/10.14506/ca35.3.03 [Access 31 August 2021].

World Urbanization Prospects: The 2014 Revision, Highlights (ST/ESA/SER.A/352). United Nations. Department of Economic and Social Affairs, Population Division.

Zulu, M., and Wilhelm-Solomon, M., 2015. Tormented by umnyama: An urban cosmology of migration and misfortune in inner-city Johannesburg. In: I. Palmary, B. Hamber and L. Núñez, eds., Healing and Change in the City of Gold. Peace Psychology Book Series, vol 24. Cham: Springer, pp. 135-148. 